\title{
Productivity and rooting of olive mini-cuttings grown in a clonal mini-garden according to season
}

\author{
Josiane Vergara Casarin ${ }^{*}$, Roseane Maidana Moreira' ', Carlos Gustavo Raasch', \\ Cari Rejane Fiss Timm', Márcia Wulff Schuch'
}

Federal University of Pelotas, Pelotas, RS, Brazil

*Corresponding author, e-mail: josiane.casarin@hotmail.com

\begin{abstract}
The mini-cuttings productivity in clonal mini-garden using the semi-hydroponic system is a promising technique for the olive propagation, to obtaining a satisfactory amount of cuttings and with good quality. The objective was to evaluate the mini-stumps productivity and rooting of olive mini-cuttings in successive collections at different times of year in a clonal mini-garden in a semi-hydroponic system. In each collection the productivity of the clonal mini-garden was evaluated counting the collected cuttings. The mini-cuttings were prepared with $3-5 \mathrm{~cm}$ long with leaf area reduced by $50 \%$ and placed in plastic boxes with vermiculite for a period of 80 days. The evaluated variables were: mini-stumps productivity, mini-stumps and mini-cuttings percentage of survival, rooting percentage and number and length of mini-cuttings root. The olive mini-cuttings presented higher productivity during the spring of 2014. The mini-cuttings rooting percentage collected during the evaluated periods demonstrated that mini-cutting is a viable technique for olive propagation when grown in clonal mini-garden using a semihydroponic system.
\end{abstract}

Keywords: fruit growing, Olea europaea, propagation, cropping system

\section{Introduction}

In Brazil the olive tree growing is recent and the production is still insufficient to supply the national market, being the country one of the largest importers of olive and olive oil in the world, with Argentina, Spain and Portugal being the main suppliers (Oliveira et al., 2009; Vieira Neto et al., 2010).

The main form of olive propagation is by cuttings. Vegetative propagation is the most widely used technique in olive producing countries and according to Silva et al. (2012b), several factors can affect the cuttings rooting potential, including the cultivar, the time of the year in which the cutting is performed, the phenological stage and the environmental conditions.

The mini-cutting emerged as a variation of cuttings in the propagation of the Eucalyptus genus and is a promising technique to the crop good quality and amount of the propagation material obtained, according to Cappellaro (2013), studying olive mini-cuttings of the cultivar Arbequina in the spring season, reaching $90 \%$ of rooting.

The mini-cutting technique consists of keeping the plants in containers, where, after pruning the apices, they emit sprouts that will be collected at regular intervals and staked, resulting in seedlings for commercial planting. In relation 
to the conventional cutting technique, minicutting presents advantages such as: exemption of the clonal, easier pathogens control, higher productivity, greater mini-cuttings production per unit area and in a shorter time, better quality of root system and reduction of seedlings formation time (Wendling \& Dutra, 2008).

The clonal mini-garden are orchards formed by parental plants, whose purpose is the propagules production, forming seedlings with quality, destined to the implantation of orchards and commercial nurseries. The advantage of this type of orchard is that, while a single matrix provides a limited amount of propagules, the clonal mini-garden allow the obtaining of a higher amount of genetically identical propagation material (Cavalcanti Júnior, 2000). The development of clonal mini-gardens with the objective of producing propagating material is advantageous, since, besides allowing the collection of branches throughout the year, they present vegetative vigor and juvenile characteristics, which is favorable to rooting (Oliveira et al., 2010).

The use of clonal mini-gardens for the production of mini-cuttings is being used in several crops, such as guava (Freitas et al., 2013), 'pitangueira' (Peña et al., 2015), blueberries (Affonso et al., 2015) and forestry species such as Cedrela fissilis (Xavier et al., 2003), Toona ciliata (Souza et al., 2014) and Paulownia fortunei (Stuepp et al., 2015).

Thus, the aim of this study was to evaluate the productivity and the rooting of olive mini-cuttings in the successive times of the year in a clonal mini-garden cultivated in a semihydroponic system.

\section{Material and methods}

The experiment was conducted in a greenhouse with plastic cover, belonging to LabAgro of the Department of Phytotechny of the Faculty of Agronomy 'Eliseu Maciel' - Federal University of Pelotas.

The clonal mini-garden consisted of trapezoidal-shaped flowerbeds, filled with $5 \mathrm{~cm}$ layer of medium gravel on the bottom and medium granulometry sand on the top, previously washed with rainwater, forming a semi-hydroponic system.

The used mini-stumps were produced by rooting mini-cuttings. The semi-hydroponic system consisted of 12 mini-stumps per flowerpot with 80 days of rooting for the cultivar Arbequina, spaced $0.10 \times 0.10 \mathrm{~cm}$. The seedlings were manually irrigated with approximately one liter of nutrient solution per flower, formulated according to Schuch \& Peil (2012) and to the needs of the olive tree. In order to avoid salinization in the semi-hydroponic cultivation system, a rainwater slide was applied twice a week.

After 90 days (adaptations and growth), the first mini-stumps were collected. Seven collections were made from fall, 2013 to the spring, 2014, with intervals of 90 days. The collected buds were counted to obtain the average productivity of the mini-stumps of the clonal mini-garden. It was also evaluated the survival index throughout the collection period.

After collecting the material, the minicuttings were prepared, with $3-5 \mathrm{~cm}$ in length, two pairs of buds and the leaves had their area reduced by $50 \%$. At the base of the cuttings, two superficial lesions were performed using a scalpel and then immersed for ten seconds in an indolbutyric acid solution (IBA), at a concentration $3000 \mathrm{mg} \cdot \mathrm{L}^{-1}$, and placed in transparent plastic boxes articulated with a Sampack ${ }^{\circledR}$ cap, with medium expanded vermiculite substrate. The volume of $1 \mathrm{dcm}^{3}$ of vermiculite and $500 \mathrm{~mL}$ of distilled water was placed in each pot.

Afterwards, they were conditioned in a greenhouse with controlled temperature at $25 \pm 2^{\circ} \mathrm{C}$ for 80 days. The evaluated variables were: productivity and survival of mini-stumps, percentage of survival (mini-cuttings that remained alive, with or without roots) and rooting of mini-cuttings (mini-cuttings with induction of root primordia, with at least $1 \mathrm{~mm}$ in length), the number of roots (considered only those that originated directly from mini-cuttings) and the length of roots by mini-cuttings $(\mathrm{cm})$.

The experiment was conducted in a completely randomized design with four replicates of 30 mini-cuttings. The data was submitted to the Shapiro-Wilk test, in order to verify the data normality. As the data did not present normal distribution, the transformation was done 
through the arcsen $\sqrt{ } / 100$ for the percentage of survival and rooting of mini-stumps and $\sqrt{ } x+0.5$ for productivity and number of roots. Data was submitted to variance analysis and the means compared by the Scott-Knott's test at $5 \%$ of error probability. The software GENES was used for the analyses (Cruz, 2013).

\section{Results and Discussion}

Significant differences were observed for the mini-cuttings productivity according to the season of collection, with highest numbers during spring, 2014 and lower numbers during the winter of 2013 and 2014 (Table 1).

Table 1. Means of olive mini-stumps productivity, olive mini-stumps survival and olive mini-cuttings survival from cultivar Arbequina in a semi-hydroponic system according to the season.

\begin{tabular}{cccc}
\hline $\begin{array}{c}\text { Season/year of } \\
\text { the collections }\end{array}$ & Mini-stumps productivity & Mini-stumps survival (\%) & Mini-cuttings survival (\%) \\
\hline Fall/2013 & $7.48 \mathrm{c}$ & $100 \mathrm{a}$ & $86.75 \mathrm{a}$ \\
Winter/2013 & $3.71 \mathrm{~d}$ & $100 \mathrm{a}$ & $80.75 \mathrm{~b}$ \\
Spring/2013 & $11.38 \mathrm{c}$ & $97.92 \mathrm{a}$ & $71.75 \mathrm{~b}$ \\
Summer/2014 & $20.21 \mathrm{~b}$ & $95.84 \mathrm{a}$ & $75.25 \mathrm{~b}$ \\
Fall/2014 & $9.13 \mathrm{c}$ & $95.84 \mathrm{a}$ & $87.5 \mathrm{a}$ \\
Winter/2014 & $6 \mathrm{~d}$ & $95.84 \mathrm{a}$ & $100 \mathrm{a}$ \\
Spring/2014 & $26.36 \mathrm{a}$ & $95.84 \mathrm{a}$ & $92.5 \mathrm{a}$ \\
\hline CV(\%) & 22.52 & 4.07 & 13.30 \\
\hline${ }^{*}$ Means followed by the same lowercase letters in the column are not different according to the Scott-Knott's test at 5\% of error probability. No- number; cm.- centimeters.
\end{tabular}

Xavier et al. (2003), studying a clonal mini-garden of Cedrela fissilis, also observed a reduction in productivity in periods with lower temperatures. The authors suggest that it occurred due to the less favorable physiologic conditions for the development process and for the mini-stumps growing.

According to the environmental variations and according to the specific characteristic of the season, it is possible to occur variation for the buds production in the ministumps e for the percentage of rooting of the mini-cuttings. According to Stuepp et al. (2015), a good productivity in a clonal mini-garden is primordial for the succes in the mini-cuttings propgation, being a key for the viability.

The average production of mini-cuttings was alternated during the seven collections, and in the seasons with lower temperatures, the productivity was reduced. Xavier et al. (2003) and Souza et al. (2014), using mini-cuttings of Cedrella fissilis and Toona ciliata, respectively, also observed the same behavior with periods of higher production alternated with periods of lower productivity of mini-cuttings.

According to Affonso et al. (2015), the increase in the productivity of mini-cuttings of blueberry tree in a clonal mini-garden occurred during summer, which is the period of the year with higher photoperiod and temperature, providing greater vegetative growth of the matrix plants. Peña et al. (2015), also reported increased productivity in the period of highest temperature in 'pitangueira' clonal mini-garden. According to the authors, the temperature possibly contributed to the development of buds and bud growth. A similar fact was observed in samples collected in the clonal mini-garden for olives in the spring and summer of 2014. According to Figure 1, the highest temperatures coincide with the period of higher productivity of the mini-cuttings. The period of lower productivity can be observed in months with lower temperatures, occurring from May to August of 2013 and 2014.

For mini-stumps survival, no statistical difference between the seven collection seasons was observed (Table 1). Affonso et al. (2015), studying blueberry trees in a clonal micro-garden in a semi-hydroponic system obtained $98 \%$ of survival for the matrix plants from the cultivar Woordard. According to the authors, these results occurred due to the good adaptability of the crop in the tested system. High survival percentages of mini-stumps were observed by por Gatti et al. (2011), with $98 \%$ of survival for the 'jequitibá' (Cariniana estrellensis) mini-stumps, by Peña et al. (2015), with $99,28 \%$ of survival for the 'pitangueira' (Eugenia uniflora L.) mini- 


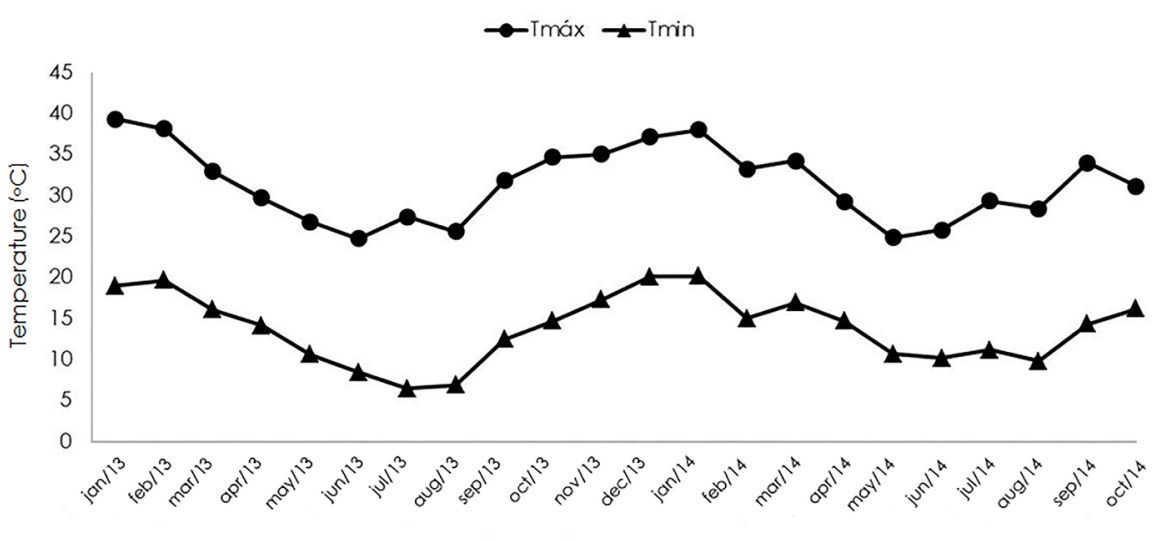

Months

Figure 1. Monthly means for the maximun and minumum temperatures (oC) during the clonal minigarden development of olive mini-cuttings.

stumps and by Silva et al. (2012a), with $100 \%$ for Australian cedar (Toona ciliata), after successive mini-cuttings collections.

In all sampling periods it was possible to verify high values for the survival of the olive ministumps in the semi-hydroponic system. According to Wendling et al. (2007), the authors observed a survival rate of over $90 \%$ of the llex paraguariensis mini-stumps, which indicates the maintenance of the viability of the mini-stumps through the collections. According to Souza Junior et al. (2008), the authors point out that high survival (over 90\%) of mini-stumps is common in clonal mini-gardens for most species, when proper management of the mini-stumps is carried out together with efficient mineral nutrition. This fact was verified for the clonal mini-garden of olive trees in the semi-hydroponic system, since from the fourth collection of mini-cuttings, the survival of the mini-stumps remained stable until the last collection, indicating the adaptation of the matrix plants to the cultivation system used and also evidencing that is a viable technique for the production of mini-cuttings of olive trees.

In the analysis of the survival of minicuttings of olive tree, a statistical difference between the seven seasons of collection was observed. The seasons with the greatest survival of mini-cuttings were the winter of 2013 with $86.75 \%$, fall with $87.5 \%$, winter with $100 \%$ and spring of 2014 with $92.5 \%$ (Table 1). Similar results were obtained by Brondani et al. (2010), which showed the best survival rates for eucalyptus clones in the colder seasons (fall winter) and the lowest in the hottest seasons (spring and summer). Altoé et al.
(2011), also reported that the season in which the mini-cutting is collected had an effect on the survival index for guava cultivars, so that the highest averages occurred in winter (June) and the lowest in summer (December).

According to data of the Table 1, there were values above $70 \%$ of survival of minicuttings during the seven successive collections. According to Freitas et al. (2013), the factors that may have contributed to this result are the physiological conditions, temperature conditions, humidity and management of the clonal minigarden, in which the propagules were submitted during the experiment period.

Statistical differences were observed for rooting percentage according to the season of collection. The highest values were obtained in the fall of 2013 with $84 \%$ and in fall, winter and spring of 2014 with $85.75 \%, 98.5 \%$ and $92.5 \%$, respectively, and the lowest rooting percentages were in the winter with $54,25 \%$, in the spring with $68.25 \%$ in 2013 and in the summer, 2014 with $65.75 \%$ (Table 2).

According to Gatti et al. (2011), several factors influence rooting, among them the temperature, humidity, light, substrate, maturity and rejuvenation capacity, season, nutrition and physiological and environmental conditions of the matrix plant, hormones and genetic factors. The degree of success of the propagation will depend on the interaction between these factors, the possibility of manipulation and the knowledge of each specie needs. For Dias et al., (2012), the environmental variations and the characteristics of each season of the year are 
Table 2. Means of rooting percentage, root number and length $(\mathrm{cm})$ of olive mini-cuttings of the Arbequina cultivar in a semi-hydroponic system at different seasons of the year.

\begin{tabular}{cccc}
\hline Season/Year of collection & Rooting (\%) & No of roots & Root lenght $(\mathrm{cm})$ \\
\hline Fall/2013 & $84 \mathrm{a}$ & $5.46 \mathrm{~b}$ & $1.53 \mathrm{a}$ \\
Winter/2013 & $68.25 \mathrm{~b}$ & $2.05 \mathrm{c}$ & $1.68 \mathrm{a}$ \\
Spring/2013 & $54.25 \mathrm{~b}$ & $1.94 \mathrm{c}$ & $0.42 \mathrm{~b}$ \\
Summer/2014 & $65.75 \mathrm{~b}$ & $2.90 \mathrm{c}$ & $1.09 \mathrm{~b}$ \\
Fall/2014 & $85.75 \mathrm{a}$ & $3.68 \mathrm{~b}$ & $1.5 \mathrm{a}$ \\
Winter/2014 & $98.5 \mathrm{a}$ & $4.59 \mathrm{~b}$ & $1.51 \mathrm{a}$ \\
Spring/2014 & $92.5 \mathrm{a}$ & $8.65 \mathrm{a}$ & $1.03 \mathrm{~b}$ \\
\hline $\mathrm{CV}(\%)$ & 18.88 & 27.31 & 37.69 \\
\hline *Means followed by the same lowercase letters in the column are not different according to the Scott-Knott's test at 5\% of error probability. No-number; cm.-centimeters.
\end{tabular}

factors that can cause variation in the production of buds in the mini-stumps and rooting of the minicuttings.

According to the data obtained in this study for olive mini-cuttings, although there is alternation in rooting during the seasons, it can be observed above $54 \%$ of rooting. The values found in this study for all collections are superior to those observed by Silva et al. (2012), in which the authors obtained $26 \%$ and $24 \%$ of rooting for olive cultivar Arbequina' cuttings cultivated in April (fall) and August (winter), respectively.

According to Oliveira et al. (2012), the authors emphasize that the juvenility and vegetative vigor of the mini-stumps are factors that directly reflect the mini-cuttings rooting. The age of the material is one of the main characteristics in a clonal mini-gardens, due to the successive collections. According to Wendling et al., (2007) and Alcântara et al. (2007), the use of mini-cuttings from a juvenile material presents good characteristics for rooting. Another factor reported by Alcântara et al. (2007), is that the increase in rooting percentage is related to the adequate balance between plant regulators, facilitating the root initiation process.

The highest number of roots in the seven collections was obtained in the spring of 2014 with an average of 8.65 and the lowest values were found in the spring and winter of 2013 with 1.94 and 2.05 and in the summer of 2014 with 2.90 roots (Table 2). According to Cappellaro (2013), with mini-cuttings of the cultivar Arbequina, the best times of the year aiming to obtain the highest number of roots were the spring, with 5.98 roots, followed by summer (4.88) and winter (2.37). According to Silva et al. (2012), the best time of the year aiming higher number of roots from cuttings of the cultivar Arbequina is in April (fall), with 6 roots, and in August (winter), with lower number of roots $(2,7)$. In this way, the greatest number of roots in the olive tree is not conditioned at a certain time of the year. According to Alcântara et al. (2007), mini-cuttings that develop a better root system quality in terms of vigor, uniformity and volume reflect positively on the survival and performance of seedlings in the field.

The seasons which resulted in the longest root length were winter $(1.68 \mathrm{~cm})$ and fall $(1.53$ $\mathrm{cm}$ ) of 2013 and winter $(1.51 \mathrm{~cm})$ and fall $(1.5 \mathrm{~cm})$ of 2014. During the spring of $2013(0.42 \mathrm{~cm})$ and spring $(1.03 \mathrm{~cm})$ and summer $(1.09 \mathrm{~cm})$ of 2014 , the lowest root lengths were observed (Table 2).

Ferriani et al. (2011), also observed in winter better results for the mini-cuttings of Piptocarpha augustifolia root length. However, results obtained by Cappellaro (2013) indicated that in summer is possible to obtain a longer root length $(2.74 \mathrm{~cm})$, followed by spring $(2.09 \mathrm{~cm})$ and winter $(1.09 \mathrm{~cm})$ for olive mini-cuttings cultivar Arbequina.

\section{Conclusions}

The higher survival and rooting percentages of mini-stumps during the successive collections confirm that the mini-cutting is a viable technique for the olive propagation in a clonal mini-garden using the semi-hydroponic system.

The seasons with lower temperatures are less favorable for the olives mini-cuttings productivity in a clonal mini-garden using the semi-hydroponic system.

\section{Acknowledgments}

To the Coordination for the Improvement of Higher Education Personnel (Capes) for the 
scholarship.

To the Rio Grande do Sul State Foundation for Research Support (FAPERGS) and National Council of Scientific and Technological Development (CNPq).

\section{References}

Affonso, L.B., Peil, R.M.N., Schuch, M.W., Cappellaro, T.H., Ozelame, G.L.C. 2015. Microjardim clonal de mirtileiro em sistema de cultivo sem solo. Revista Brasileira de Fruticultura 37:1037-1044.

Alcântara, G.B., Ribas, L.L.F., Higa, A.R., ZuffellatoRibas, K.C., Koehler, H.S. 2007. Efeito da idade da muda e da estação do ano no enraizamento de miniestacas de Pinus taeda L. Revista Árvore 31:399-404.

Altoé, J.A.A., Marinho, C.S., Terra, M.I.C., Carvalho, A.J.C. 2011 . Multiplicação de cultivares de goiabeira por miniestaquia. Bragantia 70:801809.

Brondani, G.E., Wendling, I., Grossi, F., Dutra, L.F., Araujo, M.A. 2010. Miniestaquia de Eucalyptus benthamii x Eucalyptus dunnii: sobrevivência e enraizamento de miniestacas em função das coletas e estações do ano. Ciência Florestal 20:453-465.

Cappellaro, T.H. 2013. Produção de mudas de oliveira em sistemas de cultivo sem solo. $105 f$. (Tese de Doutorado) - Faculdade de Agronomia Eliseu Maciel, Universidade Federal de Pelotas, Pelotas, Brasil.

Cavalcanti Júnior, A.T. 2000. Formação dos jardins clonais na Embrapa Agroindústria Tropical. Embrapa Agroindústria Tropical, Fortaleza, Brasil. 4p. (Instruções Técnicas, 3).

Cruz, C.D. 2013. GENES - a software package for analysis in experimental statistics and quantitative genetics. Acta Scientiarum Agronomy 35:271-276.

Dias, P.C., Oliveira, L.S., Xavier, A., Wendling, I. 2012. Estaquia e miniestaquia de espécies florestais lenhosas do Brasil. Pesquisa Florestal Brasileira 32:453-462.

Ferriani, A.P., Zuffellato-Ribas, K.C., Helm, C.V., Boza, A., Wendling, I., Koehler, H.S. 2011 . Produção de brotações e enraizamento de miniestacas de Piptocarpha angustifolia. Pesquisa Florestal Brasileira 31:257-264.

Freitas, J.A.A., Marinho, C.S., Freitas, I.L.J. 2013. Goiabeiras Paluma, Pedro Sato e Cortibel 6 propagadas por miniestaquia e miniestaquia seriada. Ciência Rural 43:1351-1356.

Gatti, K.C., Gonçalves, R.C., Xavier, A., Paiva,
H. 2011. Propagação vegetativa de jequitibá Cariniana estrellensis (Raddi) por miniestaquia. Temas Agrarios 16:54-63.

Oliveira, A.F., Chalfun, N.N.J., Alvarenga, A.A., Vieira Neto, J., Pio, R., Oliveira, D.L. 2009. Estaquia de oliveira em diferentes épocas, substratos e doses de AlB diluído em $\mathrm{NaOH}$ e álcool. Ciência e Agrotecnologia 33:79-85.

Oliveira, A.F., Vieira Neto, J., Villa, F., Silva, L.F.O. 2010. Desempenho de jardins clonais de oliveira obtidos por estaquia e enxertia em cortes sucessivos. Scientia Agraria 11:299-305.

Oliveira, L.S., Xavier, A., Dias, P.C., Correia, A.C.G., Borges, S.R., Takahashi, E.K., Paiva, H.N. 2012. Enraizamento de miniestacas e microestacas de clones de Eucalyptus urophylla $\times$ E. globulus e de Eucalyptus grandis x E. globulus. Scientia Forestalis 40:507-516.

Peña, M.L.P., Zanette, F., Biasi, L.A. 2015. Época de coleta e ácido indolbutírico no enraizamento de miniestacas de pitangueira. Semina: Ciências Agrárias 36:3055-3068.

Schuch, M.W., Peil, R.M.N. 2012. Soilless cultivation systems: A new approach in fruit plants propagation in the south of Brazil. In: International Symposium on Advanced Technologies and management towards sustainable greenhouse ecosystems-Green Syszoll. 2011. Acta Horticulturae 952:877-883.

Silva, L.F.O., Oliveira, A.F., Pio, R., Zambon, C.R., Oliveira, D.L. 2012. Enraizamento de estacas semilenhosas de cultivares de oliveira. Bragantia 71:488-492.

Silva, M.P.S., Barroso, D.G., Souza, J.S., Ferreira, D.A., Carneiro, J.G.A. 2012a. Enraizamento de miniestacas e produtividade de minicepas de cedro australiano manejadas em canaletões e tubetes. Ciência Florestal 22:703-713.

Silva, L.F.O., Oliveira, A.F., Pio, R., Alves, T.C., Zambon, C.R. 2012b. Variação na qualidade do azeite em cultivares de oliveira. Bragantia 71:202209.

Souza Junior, L., Quoirin, M., Wendling, I. 2008. Miniestaquia de Grevillea robusta A. Cunn. a partir de propágulos juvenis. Ciência Florestal 18:455-460.

Souza, J.S., Barroso, D.G., Silva, M.P.S., Ferreira, D.A., Gravina, G.A., Carneiro, J.G.A. 2014. Produtividade de minicepas de cedro australiano e remoção de nutrientes pela coleta sucessiva de miniestacas. Ciência Florestal 24:71-77.

Stuepp, C.A., Zuffellato-Ribas, K.C., Koehler, H.S., Wendling, I. 2015. Rooting mini-cuttings of Paulownia fortunei var. mikado derived from 
clonal mini-garden. Revista Árvore 39:497-504.

Vieira Neto, J., Cançado, G.M.A., Oliveira, A.F., Mesquita, H.A., Lúcio, A.D., Silva, L.F.O. 2010. Fertilizantes na produção de mudas de oliveira 'Arbequina'. Scientia Agraria 11:49-55.

Xavier, A., Santos, G.A., Wendiling, I., Oliveira M.L. 2003. Propagação vegetativa de cedro-rosa por miniestaquia. Revista Árvore 27:139-143.

Wendling, I., Dutra, L.F., Grossi, F. 2007. Produção e sobrevivência de miniestacas e minicepas de erva-mate cultivadas em sistema semihidropônico. Pesquisa Agropecuária Brasileira 42:289-292.

Wendling, I., Dutra, L.F. 2008. Solução nutritiva para condução de minicepas de erva-mate (llex paraguariensis St. Hil.) em sistema semihidropônico. Embrapa Florestas, Colombo, Brasil. 4p. (Circular Técnica, 157). 